\title{
LITERACY, LEARNING AND TECHNOLOGY STUDIES
}

Ilana Snyder

Universidad de Monash

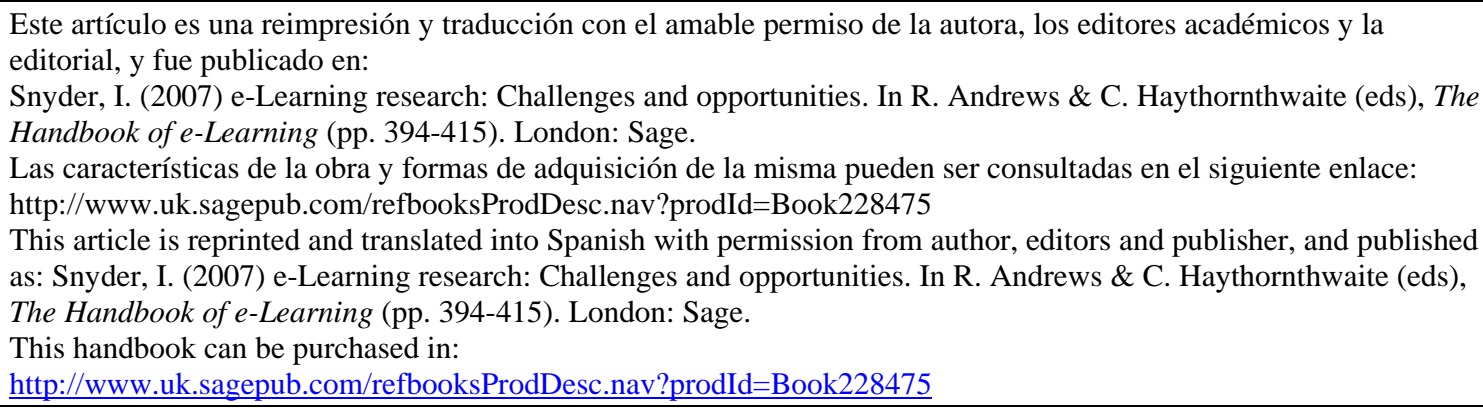

\section{Resumen}

Este artículo realiza una revisión del concepto de e-learning y un repaso de las principales tendencias sobre prácticas de alfabetización tecnológica crítica que interesan como marco de análisis de lo que hacen las escuelas y las universidades con la comunicación, la cultura, la percepción de los jóvenes y una actividad educativa más innovadora, y de cuál es su proyección en la sociedad contemporánea. Se basa en la corriente de New Literacy Studies (NLS) y el giro visual. Son: cambio de textos y prácticas, prácticas de alfabetización tecnológica en enseñanza formal e informal, nuevas formas culturales e innovación y cambio tecnológicamente mediados, y de cómo penetran en prácticas sociales y prácticas educativas universitarias.

\section{Palabras clave}

e-learning, alfabetización tecnológica, enfoque sociocrítico, universidad.

\section{Abstract}

This article reviews the concept of e-learning and an overview of major trends in critical technological literacy practices that concern as a framework for analysis of what makes schools and universities with communication, culture, youth scope and innovative educational activity, and what is its projection in contemporary society. It is based on the current New Literacy Studies (NLS) and the visual turn. They are: change of texts and practices, technological literacy practices in formal and informal education, new cultural forms and innovation and change technologically mediated, and how they enter in social and university educational practices.

\section{Key words}

e-learning, technological literacy, sociocritical approach, Higher education. 


\section{What's in a name?}

What's in a name? That that we call a rose

By any other word would smell as sweet.

(Romeo and Juliet, II, ii, 1-2)

Juliet's famous lines about the importance of words and names are salutary for elearning research in higher education. Juliet compares Romeo to a rose and reasons that if a rose were given another name it would still be a rose, just as if Romeo renounced his family name he would still be Romeo. Juliet loves the person who is called Montague; she does not love the name Montague. For Juliet, a name is an artificial and meaningless convention, not as important as what it represents.

A far cry from Renaissance Verona, but also illustrative of the tension between a name and what it might mean, is the distinction in contemporary Israel between the two words used to denote the barrier dividing Jewish settlers from Arabs in the West Bank. Many Israelis refer to it as a fence while most Palestinians would describe it as a wall. Although the image that consistently appears on television is of a high concrete construction, when you drive through the West Bank you see that the barrier is both a fence and a wall. In the main, it is a barbed wire construction with only intermittent high, solid sections that resemble the sound barriers on freeways. In the volatile context of Israeli Palestinian politics, both the names and what they represent are of considerable importance. It is either a wall or a fence depending on your ideological position.

In the field of technology-mediated learning, the issue of names is less charged but, nonetheless, significant. As evidenced by the studies distilled in this handbook, researchers use a number of terms, sometimes distinctively and sometimes interchangeably, to identify the central constructs that inform their work. The editors of this volume have selected e-learning as the organizing principle to signify the body of research that investigates, explores and theorizes teaching and learning mediated by the use of new information and communication technologies in the higher education sector. What we mean by the term 'e-learning', as well as what we mean by other key terms, is important, as it shapes the way the field is conceived, described, examined, understood and critiqued. The explanations have implications for a goal probably implicit in most of the chapters in this volume: to improve teaching and learning when digital technologies are used in higher education.

\section{The meaning of e-learning}

In Keywords, Raymond Williams (1976) points out that when some people see a word they think the first thing to do is to define it. Dictionaries are produced and with authority a meaning is provided. For certain words this kind of definition may be effective, but for words that involve ideas and values 'it is not only an impossible but an irrelevant procedure' (Williams, 1976: 17). 
The New Shorter Oxford English Dictionary on Historical Principles (Trumble and Stevenson, 2002) does not have an entry for e-learning but it does define the prefix 'e' and, of course, 'learning':

e- prefix[from e- (in ELECTRONIC adjective) after EMAIL noun.]

Denoting the use of electronic data transfer in cyberspace for information exchange and financial transactions, esp. through the Internet.

e-book noun an electronic version of a printed book that can be read on a personal computer or handheld device designed specifically for this purpose.

e-commerce noun commercial transactions conducted electronically on the Internet.

e-zine noun a magazine only published in electronic form on a computer network.(Oxford: 781)

The definition associates the prefix with the use of the Internet, involving electronic form and some kind of electronic exchange. I have always been reticent in using the prefix in the context of learning because of the strong association between ' $e$ ', the Internet and commercial activities.

The Oxford defines learning as:

$1 \mathbf{a}$ The action of LEARN verb. $\mathbf{b}$ Education; schooling.

2 Knowledge acquired by systematic study; the possession of such knowledge.

3 A thing learned or taught; a lesson, an instruction; information; a doctrine; a maxim; a branch of learning; an acquired skill. (Trumble and Stevenson, 2002: 1562)

The definition emphasizes that learning is an active state that involves systematically acquiring knowledge or skills. It presents learning as possible and unproblematic. A definition of e-learning is achieved by combining the meaning for ' $e$ ' with that for 'learning'. The result is something like 'learning conducted electronically via the Internet' or 'learning electronically'. But this definition, similar to those in other dictionaries, such as the Macquarie (Yallop et al., 2005), does not convey the idea that learning and gaining knowledge represent complex social and cultural practices.

While Williams argues that historical dictionaries go beyond limited meanings, even the New Shorter Oxford Dictionary on Historical Principles does not get us very far in understanding what learning electronically means. As Williams explains, there are difficulties in any kind of definition because the meaning of a word such as 'learning' is embedded in relationships and in processes of social and historical change. In his view, no word ever finally stands on its own; it is always an element in the social process of language.

These understandings of words and their meanings inform the question central to this chapter: to what extent is the mainly Preschool to Grade 12 (end of secondary education) (P-12) research that has investigated critical literacy and learning when digital technologies are used relevant to e-learning in higher education? Following Williams, I have identified and explain below four keywords that are central to the research reports, debates and discussions in the P-12 literature: literacy, learning, technology and critical. Although common 
in everyday usage, these words are understood in different ways by different people. Further, they are highly contested and value-laden, that means that any explanations are unlikely to be accepted by all readers. However, despite these difficulties, the concepts are integral to an understanding of the research that has concentrated on young people's in- and out-of-school literacy practices since computers were first introduced into schools en masse in the early 1980s. Of the four, literacy is the least familiar in the context of higher education, that makes the discussion of its meaning, as well as those of the others, an important preface to the overview of the P-12 literature that follows. Of course, the complex issues surrounding elearning in higher education cannot be understood simply by considering the words that might be used to discuss them. But at the same time, the issues cannot really be thought through unless we are conscious of keywords as elements of the issues. The discussion of these words represents an inquiry into a vocabulary, a shared body of words and meanings concerned with educational practices and institutions in the twenty-first century (cf. Williams, 1976).

\section{Why literacy, learning, technology and critical?}

Although I have argued that these four concepts are central to the research reports, debates and discussions in the P-12 literature, another researcher might have come up with a different cluster of words or, at least, different forms of the words. However, this possibility does no more than affirm Williams's observation that each of us has different values and that we use language differently - especially when strong feelings or important ideas are in question, as they are in the context of Israeli/Palestinian politics and as they also are in relation to e-learning in higher education. I have chosen literacy and learning rather than e-literacy and e-learning to avoid evoking the world of business by adding the prefix ' $e$ ', but also because in the P-12 literature they have been used more commonly. As our explanations of literacy and learning need to take account of the expanding use of digital technologies in the production of information and knowledge, I have also chosen technology; others might have chosen computers. I've included the word 'critical', not to signal denigration or crisis, but to emphasize that in the age of the Internet the imperative for critical engagement is stronger than ever. Finding ways to promote critical approaches that enable students in higher education to recognize the constructedness of new media texts is an important goal. I hope that the terms I have selected will be encountered critically as they have meanings that are to be tested, confirmed, asserted, qualified perhaps changed.

\section{Literacy}

Moving beyond narrowly conceived explanations of literacy, rendered simply as encoding and decoding language, more recent explanations take account of social phenomena and often refer to it as a social practice (Street, 1984). These versions also critique inadequate views of literacy that fail to look 
further than teaching and learning and the classroom: literacy studies investigate reading and writing in diverse areas including everyday life and the workplace (Barton, 2001). Literacy is not fixed but is always changing; it covers a range of cultures and historical periods, as well as multilingual contexts. Literacy is also concerned with the use of digital technologies, including the Internet. Literacy studies recognize that successive advances in technology extend the boundaries of what was previously possible and that each technological advance has seen a corresponding change in how literacy is practised and its social role understood (Lankshear and Snyder, 2000; Lankshear and Knobel, 2003).

Technological literacy (also known as silicon, digital, techno-literacy, information literacy and e-literacy, etc.) refers to the capacity to access networked computer resources and use them (Snyder, 2001, 2002). It is the ability to use and understand information in multiple formats from a wide range of sources when it is presented via computers. The Internet broadens the literacy experience from the world of print by incorporating video, hyperlinks to archived information, sound clips, discussion areas, supporting databases and related software. Acquiring technological literacy involves becoming proficient with a set of important skills. The most essential of these is the ability to make informed judgements about the information that is found online, for, unlike conventional media, much of the Internet is unfiltered by editors. Despite the speed of change in the digital world, core literacies still include Internet searching, hypertextual navigation, content evaluation and knowledge assembly (Gilster, 1997).

\section{Learning}

From a sociocultural perspective, learning is a complex activity. It is about becoming proficient participants in social practices. The situated social practice model (e.g. Rogoff, 1984, 1990; Lave and Wenger, 1991), derived from the pioneering work of Vygotsky (1962), is particularly useful. This model emphasizes situated learning within authentic contexts through processes like cultural apprenticeship, guided participation and participatory appropriation (Rogoff, 1995), involving people with different degrees of experience, engaging with each other, and moving through cycles of teaching, learning and practice. Within authentic settings of culturally valued activity, participants learn from each other, are guided by social and cultural values as well as by social partners, and improve their expertise by such means as explaining to and guiding others, and from sheer practice (Lankshear and Snyder, 2000).

Becoming proficient participants in a social practice typically involves a mix of acquisition and learning. As Gee explains (1996: 138), 'acquisition is a process of acquiring something (usually, subconsciously) by exposure to models, a process of trial and error, and practice within social groups, without formal teaching', while 'learning is a process that involves conscious knowledge gained 
through teaching (though not necessarily from someone officially designated a teacher) or through certain life-experiences that trigger conscious reflection'.

Learning is essential if cultural apprenticeship is to be appropriately balanced by cultural criticism and active participation. From a sociocultural perspective, learning focuses not on children or schools, but on human lives seen as trajectories through numerous social practices across a range of social institutions.

In universities, it is teachers who take responsibility for what and how students learn by creating the conditions in which understanding is possible. It is the students who take advantage of opportunities for coming to know (Laurillard, 1993). A vision of learning with growing acceptance is of young people pursuing their own objectives towards knowledge, inspired but not necessarily directed by their teachers. According to this view, when students take responsibility for their own learning they can use the classroom as offering a set of resources that are largely under their control.

Despite the popularity of this belief that teachers will become less important as students become more independent, engaging in self-directed learning, university teachers now have a heightened role: to deepen and refine students' capacity for response to cultural change, so that the changes can be constantly criticized and their implications understood and to ensure that 'the technical changes that have made our culture more dependent on literate forms are matched by a proportionate increase in training in literacy in its full sense' (Williams, 1983: 310). Although writing before the Web, Williams's admonition continues to resonate. Teachers are needed more than ever because critical technological literacy practices are cognitively and socially demanding.

Another way of thinking about learning (and literacy) in the twenty-first century is to conceive of the process as knowledge assembly: the ability to collect and evaluate information, defined as data that have been organized and communicated (Gilster, 1997). Effective information gathering can be represented as a balancing act. Used skilfully, networked information possesses unique advantages. It is searchable. It can be customized to reflect users' needs. Moreover, its hypertextual nature connects with a wide range of information sources, allowing users to consider different points of view and to make informed decisions about their validity. The process of using these tools and critically evaluating the results is knowledge assembly.

\section{Technology}

It is still common for educators to think of technology in terms of tools, implements and applications. In the age of the Internet, these would include: Web sites, multimedia, video games, CD-ROMs, DVDs and virtual reality. Although it is not wrong to think of technology in this way, it is limiting; it impedes understanding of technology's social and cultural dimensions. Like literacy, technology is a form of social practice. It represents not just the need to acquire certain skills: technology is 'an expression of the ideologies, the cultural 
norms, and the value systems of a society' (Bruce, 1999: 225). This means that talk about technology and its effects is inadequate if it remains in the realm of the technical.

Producing a list of the technical things teachers in higher education should know appears easy. A list might include learning how to: explore, evaluate and use a range of computer applications; operate a multimedia system; use certain software such as word processing, databases and spreadsheets. Just as important, however, are the underlying pedagogical values 'that might inform decisions about whether this option is appropriate for particular students in a given context, how it should be used, and how one might judge its success' (Bruce, 1999: 226). A set of questions needs to be asked. On what basis should teachers judge software? What kind of instruction is required to support the software? What do teachers want the software tools to help produce? A list of the technical requirements alone fails to connect with the fundamental issues of teaching and learning. Finding answers to these questions is a central part of everyday teaching: thinking primarily about learning is paramount, but thinking critically about the technologies that support it is also important (Lankshear and Snyder, 2000).

Although activity theory (Engeström et al., 1999) does not specifically address issues of literacy, one of the four concepts discussed in this chapter, it has been increasingly applied to contexts where the use of technology plays a major part in the learning experience. As a heuristic, activity theory enables thinking about both language and technologies as mediating or cultural tools in human learning (Vygotsky, 1962). It is concerned with context that involves a weaving together of learners with both tools and people into a 'web or network of sociocultural interactions and meanings that are integral to the learning' (Russell, 2002: 68).

Pacey's (1983) concept of technology-practice is also useful. As Bruce (1999) has more recently argued, to think of technology in terms of tools, implements, techniques and know-how alone is to limit our conception of technology to just one of its three component dimensions: the technical. If we look beyond the tool itself to see the web of human activities surrounding the machine' (Pacey, 1983: 3) we see that technology is a form of social practice and not, as is so often assumed, culturally neutral.

Looking at a machine such as a computer, the opposite may seem to be true. However, once the complex of human activities surrounding the computer's use is considered, it soon becomes apparent that technology is part of life itself and not something that can be kept in a separate compartment. In other words, technology- practice has technical, organizational and cultural dimensions. Moreover, technology is an essential aspect of humanity, since technology is found in all cultures, irrespective of geographic locale or historical period. 


\section{Critical}

Although 'critical' can be a difficult word because the its predominant sense is of either disapproval or impending crisis, in literacy studies it is often used in association with literacy to highlight the complex relationships among language, power, social groups and social practices (Knobel and Healey, 1998). Like literacy, being critical represents a practice or a process. Concerned with the development of social awareness and active, responsible citizenship, a critical approach to literacy argues that the meanings of words and texts cannot be separated from the cultural and social practices in which they are constructed. It recognizes the non-neutrality of texts and is concerned with the politics of meaning: how dominant meanings are maintained, challenged and changed.

Just as a critical approach to literacy has been recommended, so too there is a need to adopt a socially critical stance toward information and communication technologies, taking careful account of their educational applications and implications. A critical stance means understanding the place of digital technologies within contemporary history and culture and in relation to ourselves and everyday social practice. It means adopting a certain kind of orientation and attitude towards digital technologies and developing appropriate understandings and skills that involve more than simply 'learning how to drive them'. Teachers need 'to become appropriately informed and skilled with regard to new technologies, that ... means becoming critical consumers or users' (Bigum and Green, 1995: 13).

As the use of the Internet expands, attention increasingly turns to the promotion of critical technological literacy practices. Critical technological literacy is about recognizing and valuing the breadth of information available and learning how to evaluate, analyse and synthesize that information. It is also concerned with the construction of new meanings and knowledge with technology and with the capacity to communicate in a variety of media for different audiences and purposes. Moreover, it focuses on understanding the ethical, cultural, environmental and societal implications of the use of digital technologies (Faigley, 1999).

Using this vocabulary of inquiry, the next section outlines some important questions that have guided the P-12 research and presents, somewhat schematically, several influential theoretical frameworks. Although there are significant differences between the school and the tertiary sectors, such as the funding models, the organizational structures, the resources, the age of the students, the pedagogical approaches and, of course, the language used to designate key constructs, to name just a few, there are research questions and theoretical perspectives useful for all sectors. 


\section{Questions and theories pertinent to investigating digital technologies in higher education}

The questions and theories presented here are designed to contribute to thinking about critical literacy, learning and technology in the context of higher education. Four keywords have already been discussed. It is useful at this point to define a few more that are used in this chapter. In the main, the term computers signifies the hardware and software central to the research before widespread connectivity via the Internet). New media and digital technologies are used more or less interchangeably to denote the diverse technologies such as networked computers, video games, the Internet, mobile phones and DVDs that assume the centrality of the screen. Cultural form, derived from Williams's (1975) study of television technology and cultural form, is explained as a general way used by the culture to represent human experience in the world. In the context of the Internet, a cultural form might be a hypertextual essay, a chat facility, a Web log or a multi-user game.

\section{Questions}

The challenge for both teachers and researchers is to make possible the intelligent and informed use of digital technologies so that students can participate productively and ethically in their lives beyond tertiary study in a world increasingly dominated by the use of digital technologies. On the one hand, university teachers are looking for models that offer strategies that take account of digital technologies to teach students what they need to know in the Age of the Internet. On the other hand, researchers are seeking ways to explain the conceptual, visual, textual, artistic, technical and identity processes involved when digital technologies are used that might inform teaching and learning practices. Although much of the research reported here has not focused directly on higher education, it is possible to extrapolate from studies concerned more broadly with young people's engagement with new media and the implications for teaching and learning. The findings of these studies may sometimes challenge, sometimes complement and sometimes support the traditional printbased literacy practices that still dominate many university classrooms.

In their systematic investigations of the contexts in that young people use new media, researchers have asked how teachers might take account of the changes to literacy practices likely to develop in the future and needed to support communication across linguistic, cultural and geopolitical borders.

Researchers have also asked what the social practices that develop around young people's growing engagement with new media may mean for critical education. Of particular contemporary importance is researchers' interest in how teachers might handle the tension between calls for more innovative teaching and responsiveness to students' lives, on the one hand, and governments demanding greater control and accountability at the same time as they reduce funding, on the other. This tension is real in Australia, New Zealand, the UK and the US. 


\section{Theoretical approaches}

Social accounts of literacy as represented in the New Literacy Studies (NLS) offer a potent framework for investigating the use of digital technologies in higher education for teaching and learning. Indeed, the earlier discussion of the keywords was informed by an NLS approach. Researchers who have taken the social turn recognize that reading and writing are always situated within specific social contexts, and that it is these contexts that give meaning to the practices of reading and writing. The New Literacy Studies, conceived as a body of independent yet linked work produced over the past twenty years, across a number of disciplines, including anthropology, history, psychology and sociolinguistics, exemplifies the social approach to literacy research (Scribner and Cole, 1981; Heath, 1983; Street, 1984; Gee, 1996; Barton and Hamilton, 1998).

Rather than defining literacy as a set of static skills, taught in schools and associated with books and writing, NLS research examines literacy practices and events looking at the role of literacy in people's everyday lives (Street, 1995, 2001; Barton and Hamilton, 1998). The NLS rejects the dominant view of literacy as a neutral technical skill, conceptualizing it instead as 'an ideological practice, implicated in power relations and embedded in specific cultural meanings and practices' (Street, 1995: 1). The ways in that language is used in the context of Middle Eastern politics embodies this understanding.

Not only has there been a social turn in literacy studies: there has also been what Kress (2003) calls a visual turn, that is changing the ways communication and meaning making are understood. Researchers working in this area argue that communication and learning are becoming more and more multimodal (Kress and Van Leeuwen, 1996, 2001; Jewitt and Kress, 2003). In an electronically mediated world, literacy practices include multiple forms of representation: to be literate means recognizing how different modalities are combined in complex ways to create meaning. These other modes incorporate diagrams, pictures, video, gesture, speech and sound, and researchers in the area have produced systematic accounts of the ways in that multimodal texts communicate meaning.

Also pertinent to understanding the textual practices and formations associated with the use of new media is Bolter and Grusin's (1999) theory of remediation, as it offers a compelling explanation of the complex ways in that old and new media interact. They argue that new media achieve their cultural significance by paying homage to, rivalling and refashioning earlier media such as perspective painting, photography, film and television. Bolter and Grusin call this process remediation and note that earlier media have also remediated one another: photography remediated painting, film remediated stage production and photography, and television remediated film, vaudeville and radio.

Castells (1996: 371) makes a similar point when he explains how different media borrow codes from each other so that interactive educational programmes look like video games; newscasts are constructed as audiovisual 
shows; trial cases are broadcast as soap operas; pop music is composed for MTV'. According to Bolter and Gruisin, the new literacy practices associated with the use of new media do not simply represent a break with the past: old and new practices interact in far more complex ways, producing hybrid rather than wholly new practices.

The ideas presented here have been selected to provide a theoretical context for the thematic analysis of the research that explores the use of digital technologies in a range of educational contexts that follows. Importantly, these theoretical perspectives all encourage critical engagement with culture, language and education. Finding innovative ways of developing critical pedagogies remains a central concern for all teachers across all educational sectors. However, even though the New Literacy Studies offer a particularly generative framework for thinking about the issues involved, no one theory is adequate to engage the richness, complexity, variety and novelty inherent in the literacy and learning practices associated with the use of new media (Snyder, 2002).

\section{An overview of the literacy, learning and technology research}

While the review below begins with a brief account of the first two decades of the literacy, learning and technology research (the 1980s and 1990s), the emphasis is on the second millennium, chosen as the marker of a new epoch and burgeoning research activity in this field of study. Readers will recognize efforts by researchers and practitioners to identify what is central to the project of improving teaching and learning when digital technologies are used. Notable too is the scope of methodologies the researchers bring to their studies. In their move away from cognitive models to concentrate on cultural and social aspects of language practices, many of the studies share common ground with the theoretical approaches and ethnographically oriented methodologies of the New Literacy Studies.

\section{Early Research, 1980-2000}

The first decade of research was dominated by studies that set out to determine whether the use of computers improved writing and in the main drew upon accounts of literacy conceived predominantly in psychological terms. By the mid-1980s understandings of literacy as a social practice became more widely accepted. With this increased sensitivity to the social setting in that the computers were used, some researchers shifted the focus from the isolated writer to the writer in context (e.g. Eldred, 1991); some began to explore the possibilities of the computer as a site for the social construction of knowledge (e.g. Herrmann, 1987). A number of studies began to adopt multiple perspectives (e.g. Hawisher and Selfe, 1991), while others examined computermediated literacies through a particular ideological lens (e.g. Goodson and Mangan,1996). More generally, there was a growing recognition that computers in classrooms appeared unlikely to negate the influence of 'the differential 
socialisation of students by social class' and its effects on their success or failure in education' (Herrmann, 1987: 86).

Social understandings of literacy provoked different kinds of questions and research orientations. The Digital Rhetorics study (Lankshear et al., 1997; Lankshear and Snyder, 2000) exemplified research informed by the understanding of literacy as social practice. This relatively large-scale qualitative study argued that education must enable young people to become proficient in the operational, cultural and critical dimensions of techno-literacy (Durrant and Green, 2000). However, a central finding was that teachers were so overwhelmed with operational concerns related to the use of digital technologies that they had no time for developing the critical dimension of literacy.

As in the Digital Rhetorics study, critical perspectives were gaining attention in this period. Researchers have criticized the short-sighted policy efforts of selfinterested governments, corporations and school councils and boards that have rushed to embrace technology, spending huge amounts without first asking some difficult questions about use, support and learning (e.g. Cuban, 1986, 2001). Others have pointed to the non-neutrality of computer technologies (Bowers, 1988) and how over time they tend to become naturalized, thus escaping critical examination (Burbules and Callister, 2000). Yet others have represented computers as instruments of social control and dependence (e.g. Apple, 1987).

Increasingly, the Internet has become a site for research (e.g. Jones, 1999). Informed by the understanding of literacy as a set of social practices, investigations have focused on new literacy practices (e.g. Snyder, 1997), issues of identity (e.g. Turkle, 1995), class and access (e.g. Castner, 1997), the maleness of the Web (e.g. Takayoshi et al., 1999). The findings have emphasized the need to teach students how to critically assess the reliability or value of the information they find on the Web by understanding not only its textual but also its non-textual features such as images, links and interactivity (LeCourt, 1998; Burbules and Callister, 2000).

The early research demonstrates the transition from psychological to more socially constructed conceptions of literacy, as well as the growing interest in critical evaluation as it relates to race, class, gender and information. The social turn focused attention on the importance of history as well as on other contextual influences that play a role in the constitution of classrooms, teaching, learning and achievement. The early research also began to argue for more complex understandings of the relationship between technology and society. Such understandings drew attention to the varied effects of technology in classrooms, suggesting wariness of research investigating the impact of technology on learning. A more generative direction focused on how to use technology productively in teaching and learning. Rather than regarding technology as a neutral tool for teaching and learning purposes, researchers saw the possibilities for modelling critical engagement with it so that students 
might recognize that in educational settings technology represents the varied intentions of business, government and education players.

\section{Recent research, 2000-2006}

Four general directions informed by critical understandings of literacy, learning and technology that researchers seem to be following are presented here: changing texts and practices; technological literacy practices in formal and informal education; new cultural forms; technology-mediated innovation and change. As these categories often overlap, it is sometimes difficult to make clear distinctions between them.

Although the trend has been there since the early days, more researchers are acknowledging the need to pay attention to the social, cultural and political changes associated with the use of digital technologies. Finding ways to exploit the opportunities for learning offered by digital technologies in productive ways, but at the same time helping students to become capable and critical users, is increasingly seen as a major challenge. Often implicit in reports of research is the understanding that the relationship with technology is never one-way and instrumental: it is always two-way and relational. These understandings, of course, are not universal. Further, as in most research areas, indeed, as this handbook exemplifies, there are available overviews of the research literature (e.g. Snyder, 2000; Andrews, 2004).

\section{Changing texts and practices}

Changes to texts, language practices and social formations are associated with students' use of mobile phones, text messaging, the Internet, instant messaging, online games, blogs, search engines, Web sites, e-mail, digital video, music and imaging, and more. Working with the texts produced by these new ways of communicating requires a complex set of literacies: not only verbal literacy, but also visual and audiovisual literacies. Among other things, it requires an understanding of layout and design, not often recognized as necessary with print texts. Finding the language to talk about these practices and discerning how meanings are made with them is a research concern.

Abbott (2002) has examined the ways in that students, including those with special needs, make elegant use of the visual in their Web pages, forming representations of themselves, their practices and their aspirations. Also interested in Web design, O'Hear and Sefton-Green (2004) have investigated online culture and Web authoring by young people. In addition to a consideration of the technical, institutional, aesthetic and generic determinants influencing the nature of Web-based productions, they pay attention to the fusion of visual, textual and structural elements, especially those relating to nonlinear navigation features.

Implicit in much of this research are notions of critical literacy, broadly defined, but often mobilized in different ways in online spaces. Such research has a long heritage but continues to argue that digital technologies require 
different ways of reading. Cranny-Francis (2004) maintains that young people need to know not only how to approach sites as readers looking for information and/or entertainment but also as text producers who need to understand the kinds of meanings different sites generate. Walton (2004) argues that what goes on behind the screen is just as important for users as what is visible on the screen. With a focus on the database, design and interactivity, she draws on evolving conventions in the field of Web design to account for the characteristics of new media. Walton also considers search engine logic and the ways in which it shapes online knowledge and experience. Much of this amounts to a version of critical literacy where the apparent seamlessness of new media environments is understood as the composited and constructed worlds that they are (e.g. Manovich, 2001).

In a similar way, Burbules $(1997,2002)$ has looked at hyperlinks and the ways they can become invisible and neutral. He considers their dual character as both semantic connectives and navigation elements, suggesting new metaphors for thinking about learning with, through and about digital technologies. These new metaphors posit learning as a kind of mobility that has special importance for reconceptualizing education in an Information Age. As teachers and students consider how some semiotic modes are privileged and others excluded, and how different modes can also be combined in different ways for different purposes, possibilities of thoughtful and critical engagement with a range of new and hybrid text types become available.

\section{Technological literacy practices in formal and informal education}

The pervasive take-up and presence of digital technologies, at least in the developed world, mean that students' experience of literacy is shaped by multiple engagements with digital technologies and global digital cultures. As a result, their use of technologies in a range of contexts has implications for equity and identity formation as well as for a range of other important issues. Research can provide important understandings for tertiary educators about the experiences and expectations students bring to formal studies (e.g. Hull and Schultz, 2002; Lankshear and Knobel, 2003). However, as Burbules and Callister (2000) emphasize, access to new media cannot be seen merely as having a way to use a computer with an Internet connection. Access also includes issues of who can afford a computer with an online connection, who knows how to operate the technologies and who knows how to judge what is good and what is not. Users who cannot operate effectively across the full range of opportunities that new media represent cannot be said to have true access.

In a number of large-scale studies, Livingstone and her colleagues provide insight into the complex relationship between the media, the family and the home (Livingstone, 2002). The UK project investigated how far gaining access to media goods determines or frames subsequent use, tracing the slippage between access and use. The study found the contexts of leisure, 
home and family increasingly aligned but also in tension, particularly in terms of the individualization of leisure, the loss of public leisure, together with the privatization of everyday life, even within the home, and the democratization of cross-generational relationships within the family.

Two large-scale surveys in the US provide detailed portraits of young people's media lives. The PEW Project has found that more than half of American teenagers have created content for the Internet and that most think that getting free music files is easy to do (Lenhart and Madden, 2005). The teens have produced a blog or Web page, posted original artwork, photography, stories or videos online or remixed online content into their own new creations. A survey study of 'Generation M' (Rideout et al., 2005) asked questions that ranged from broad societal issues to health concerns to issues of cognitive development. It found that young people live media-saturated lives and have access to an unprecedented amount of media in their homes. Those with easy access tend to spend more time using those media but age, gender and race influence the amount of time they spend. Those with the poorest grades spend most time with video games. And television and listening to music remain more important in their media lives than the Internet. Although they continue to read, they now spend less time with books. The findings of such surveys remind the higher education sector that students bring sophisticated skills to classrooms that might be better used for critical literacy learning.

On a smaller scale, Snyder et al. (2002) compared home and school digital literacy practices in the context of disadvantage. A year-long study investigated the ways in that four families used digital technologies to engage with formal and informal literacy learning in home and school settings. The findings drew together issues of access, equity and cultural capital and explored what it is about digital literacy practices at home and at school in disadvantaged communities that make a difference in school success. Clearly, there are further questions about the complex relations between the use of digital technologies and existing patterns of social and economic disadvantage that need to be asked. These are questions not just about physical access to the most sophisticated technology, but also about the quality and nature of such access as influenced by the cultural resources that individuals and families can bring to bear on their relationship with technology.

\section{New cultural forms}

Researchers have taken account of young people's everyday technological literacy practices in P-12 classrooms. Although these practices are largely ignored in school curricula, research is demonstrating the value popular texts offer for consolidating and extending students' understanding of technological literacy (Alvermann et al., 1999). Researchers have examined different cultural forms such as Japanese anime (Chandler-Olcott and Mahar, 2003), online role playing (Thomas, 2005), online auction and news commentary Web sites (Lankshear and Knobel, 2003), culture jamming 
(Lankshear and Knobel, 2003), horror movies and digital film production (Burn, 2000), blogging (Gurak et al., 2004), Internet chat rooms, instant messaging, and peer-to-peer music and video file sharing (Merchant, 2001; Godwin-Jones, 2005).

In a study of the use of new media, Snyder and Bulfin (2005) are examining the cultural forms with that young people engage in three domains: school, home and community. A central aim is to learn more about the complex connections between literacy practices and cultural form, but, most important, the study will consider the implications of young people's digital lives for formal teaching and learning. Building a case for the use of popular culture texts and activities in secondary classrooms, Carrington (2005: 480) argues that these texts are both 'familiar and authentic' and build links between young people's in school and out of school worlds. When teachers recognize that young people bring expertise and skills to the learning context, they can encourage the students to remix, play around and engage critically with these textual practices. These studies suggest that creative ways of learning can be employed using digital technologies that facilitate greater student motivation, greater responsibility for aspects of their own learning, enhanced technology capabilities, and the experience of achievement and success.

Another perspective on the significance of young people's out-of-school literacy activities is provided by researchers investigating video and computer games in relation to literacy learning (see McFarlane's chapter in this volume). After examining the theory of learning underpinning good video games, Gee (2003) concludes that it most closely resembles the best kinds of science instruction in schools. Gee does not argue that what people learn when playing video games is always good; rather, what they are doing when they are playing good video games often involves good learning (cf. Prensky, 2005). Gee's research suggests that there are a number of lessons teachers might learn from game designers about situated learning, reducing the consequences of failure and the power of affinity groups - relevant not just to the school sector, but also to higher education.

\section{Technology-mediated innovation and change}

When researchers write about the possibilities of creative changes to pedagogical and institutional practices when digital technologies are used, they often ask several questions. What are the optimum conditions under which innovation can thrive? Is conflict between institutional goals and pedagogical objectives inevitable? They raise these questions within the context of a culture of institutionalized education that champions innovation at the same time as it honours the value of preserving the traditional. This is further complicated by those who have a vested interest in commodifying education and who often promote technological innovation as an appealing selling point (Snyder, 1999).

One prerequisite for effective innovation and change is a strong knowledge and understanding of the history of technological literacy. Bruce (2002) takes an 
historical perspective, asking how literacies, technologies and social circumstances co-evolve and what changes in literacy practices mean for young people today. He argues that literacy becomes inextricable from community, from the ways that communities and society change and from the material means by that knowledge is negotiated, synthesised and used.

Interested in the nexus between schools and the their local communities, Bigum (2002) critiques the widely held assumption that the more schools spend on technology the better the outcomes. A similar view was once held in business and industry. However, analyses have demonstrated that there is little or no association between spending on technology and increased productivity and profitability. Bigum's research on knowledge-producing schools argues for the development of a relationship-based design sensibility for schools that shifts the focus from how to integrate digital technologies into the curriculum towards a consideration of schools as social organizations that have relationships with local communities, government and other schools. Again, the corollary for higher education is evident.

Highlighting how theory and practice can work together effectively, Pahl and Rowsell (2005) see learning as a shared enterprise between teachers and students rather than as an individual cognitive activity, concerned with the acquisition of a set of skills that can be transferred with ease from context to context. They argue that systematic engagement with everyday texts, discourses and practices is at the heart of teaching and learning. They also argue that, by acknowledging students' identities in their literacy practices, teachers can support and sustain their engagement with education. Although their focus is on P-12, it is not too great a leap to see the implications for higher education.

\section{Challenges facing e-learning in higher education}

This examination of P-12 literacy, learning and technology studies reveals some facts about the communication landscape, also pertinent to higher education. The landscape is changing, as it has always done, but more rapidly and more fundamentally. Contemporary texts are being shaped by the new uses they have been put to. They cross communication domains and are remediated to make new or hybrid texts. These changes mean that the literacies required for the future will no doubt be different and thus have significant implications for all sectors of education.

There is growing recognition that digital technologies cannot be dismissed as new tools, employed to do what earlier technologies did, only faster and more efficiently. Researchers and teachers acknowledge the social and cultural significance of digital technologies, warning against overlooking their material bases and the expanding global economic dependence on them. However, opportunities to use digital technologies in educational contexts that exploit their affordances are happening unevenly, within and between nation states, in both the developed and the developing world. 
The studies reported in this chapter explore the complexity of technologymediated education in local settings. The findings demonstrate that the changes in literacy practices can be understood when they are examined within their social, political, economic, cultural and historical contexts. When digital technologies are available in education settings, teachers have an important role to play. As students in higher education are engaging with these technologies, in contexts beyond the academy, and in the various trajectories of their lives, university teachers need to ensure that they learn how to assume a critical and informed approach while still accessible to formal education.

\section{Some questions to guide future research}

The challenge for researchers is to devise projects that will inform effective teaching and learning practices in higher education mediated by the use of digital technologies. It would be useful to undertake a longitudinal approach to the study of students immersed in computer culture at university, at home and at work. Attention also needs to be directed towards the intersection of multiple languages and the multiple modalities of the new technologies. There are many universities where multiple languages are present both inside and outside classrooms. Research could investigate the place of multilingualism and multiculturalism in technology-mediated university settings.

There is a need for further research investigating the complex relationships between the verbal and the visual in communication and representation in higher education contexts. There is also a need for further research investigating the complex relationships between literacy, technology and disadvantage. Prompted by concerns about equity, Livingstone and Bober (2005) recommend that research needs to keep up with technological and market developments in relation to access to track shifting and diversifying contexts of use, including the institutional and social influences on young people's Internet use, and to critically examine causes and consequences of exclusion.

Above all else, making critical technological literacy education better is the aim. If this is true, then the challenge for researchers and teachers is how to restructure university classrooms in response to social and technological changes, but at the same time to cater for the needs of students from diverse cultures, races and backgrounds. This chapter concludes by encouraging a critical pedagogy of literacy, technology and learning. Through the study of texts, both print and electronic, an informed critical pedagogy would aim to provide learners with a sense of their place in the world and with the capacity to develop strategies for making it a better place. 


\section{References}

-Abbott, C. (2002) 'Writing the visual: the use of graphic symbols in onscreen texts', in I. Snyder (ed.), Silicon Literacies: Communication, Innovation and Education in the Electronic Era. London: Routledge. pp. 31-46.

-Alvermann, D. E., Moon, J. S. and Hagood, M. C. (1999) Popular Culture in the Classroom: Teaching and Researching Critical Media Literacy. Newark, DE, and Chicago: International Reading Association National Reading Conference.

-Andrews, R. (ed.) (2004) The Impact of ICT on Literacy Education. London and New York: RoutledgeFalmer.

-Apple, M. (1987) The New Technology: Part of the Solution or Part of the Problem? Canberra: Curriculum Development Centre.

-Barton, D. (2001) 'Directions for literacy research: analyzing language and social practices in a textually mediated world' Language and Education, 15 (23): 92-104.

-Barton, D. and Hamilton, M. (1998) Local Literacies: Reading and Writing in One Community. London: Routledge.

-Bigum, C. (2002) 'Design sensibilities, schools, and the new computing and communications technologies', in I. Snyder (ed.), Silicon Literacies: Communication, Innovation and Education in the Electronic Era. London: Routledge. pp. 130-40.

-Bigum, C. and Green, B. (1995) Managing Machines? Educational Administration and Information Technology. Geelong, Vic.: Deakin University Press.

-Bolter, J. D. and Grusin, R. (1999) Remediation: Understanding New Media. Cambridge, MA: MIT Press.

-Bowers, C. A. (1988) The Cultural Dimensions of Educational Computing: Understanding the Nonneutrality of Technology. New York: Teachers College Press.

-Bruce, B. C. (1999) 'Response: speaking the unspeakable about twenty-first century technologies', in G. E Hawisher and C. L. Selfe (eds), Passions, Pedagogies and Twenty-first Century Technologies. Logan, UT: Utah State University Press; Urbana, IL: National Council of Teachers of English. pp. 2218.

-Bruce, B. C. (2002) 'Diversity and critical social engagement: how changing technologies enable new modes of literacy in changing circumstances', in D. E. Alvermann (ed.), Adolescents and Literacies in a Digital World. New York: Peter Lang. pp. 1-18.

-Burbules, N. C. (1997) 'Rhetorics of the Web: hyperreading and critical literacy', in I. Snyder (ed.), Page to Screen: Taking Literacy into the Electronic Era. Sydney: Allen and Unwin. pp. 102-22.

-Burbules, N. C. (2002) 'The Web as a rhetorical place', in I. Snyder (ed.), Silicon Literacies: Communication, Innovation and Education in the Electronic Era. London: Routledge. pp. 75-84. 
-Burbules, N. C. and Callister, T. A., Jr (2000) Watch IT: The Risks and Promises of Information Technologies for Education. Boulder, CO:Westview Press.

-Burn, A. (2000) 'Repackaging the slasher movie: digital unwriting of film in the classroom', English in Australia, 127-8: 24-34.

-Carrington, V. (2005) 'The uncanny, digital texts and literacy', Language and Education, 19 (6): 467-82.

-Castells, M. (1996) The Rise of the Network Society. Oxford: Blackwell.

-Castner, J. (1997) 'The clash of social categories: egalitarianism in networked writing classrooms', Computers and Composition, 14 (2): 257-68.

-Chandler-Olcott, K. and Mahar, D. (2003) 'Adolescents' anime-inspired "fanfictions": an exploration of multiliteracies', Journal of Adolescent and Adult Literacy, 46 (7): 556-66.

- Cranny-Frances, A. (2004) 'Spinning the Web: an analysis of a Web site', in I. Snyder and C. Beavis (eds), Doing Literacy Online: Teaching, Learning and Playing in an Electronic World. Creskill, NJ: Hampton Press. pp. 145-62.

-Cuban, L. (1986) Teachers and Machines: The Classroom Use of Technology since 1920. New York: Teachers College Press.

-Cuban, L. (2001) Oversold and Underused: Computers in the Classroom. Cambridge, MA: Harvard University Press.

-Durrant, C. and Green, B. (2000) 'Literacy and the new technologies in school education: meeting the I(IT)eracy challenge?' Australian Journal of Language and Literacy, 23 (2): 89-108.

-Eldred, J. M. (1991) 'Pedagogy in the computer-networked classroom', Computers and Composition, 8 (2): 47-61.

-Engeström, Y., Miettinen, R. and Punamaki, R. (eds) (1999) Perspectives on Activity Theory. Cambridge: Cambridge University Press.

-Faigley, L. (1999) 'Beyond imagination: the Internet and global digital literacy', in G. E Hawisher and C. L. Selfe (eds), Passions, Pedagogies and Twenty-first Century Technologies. Logan, UT: Utah State University Press; Urbana, IL: National Council of Teachers of English. pp. 129-39.

-Gee, J. P. (1996) Social Linguistics and Literacies: Ideology in Discourses (2nd edn). London: Taylor and Francis.

-Gee, J. P. (2003) What Video Games have to Teach Us about Learning and Literacy. New York: Palgrave Macmillan.

-Gilster, P. (1997) Digital Literacy. New York: Wiley.

-Godwin-Jones, B. (2005) 'Messaging, gaming, peer-to-peer sharing: language learning strategies and tools for the millennial generation', Language, Learning and Technology, 9 (1): 17-22.

-Goodson, I. F. and Mangan, J. M. (1996) 'Computer literacy as ideology', British Journal of Sociology of Education, 17: 65-79.

-Gurak, L., Antonijevic, S., Johnson, L., Ratliff, C. and Reyman, J. (eds) (2004) 'Into the blogosphere: rhetoric, community, and culture of weblogs', University 
of Minnesota. Retrieved 4 April 2005 online at: http://blog.lib.umn.edu/blogosphere/.

-Hawisher, G. E. and Selfe, C. L. (eds) (1991) Evolving Perspectives on Computers and Composition Studies: Questions for the 1990s. Urbana, IL: National Council of Teachers of English.

- Heath, S. B. (1983) Ways with Words: Language, Life and Work in Communities and Classrooms. Cambridge: Cambridge University Press.

-Herrmann, A. (1987) 'Ethnographic study of a high school writing class using computers: marginal, technically proficient and productive learners', in L. Gerrard (ed.), Writing at the Century's End: Essays on Computer-assisted Instruction. New York: Random House.

-Hull, G. A. and Schultz, K. (eds) (2002) School's Out: Bridging Out-of-school Literacies with Classroom Practice. New York: Teachers College Press.

-Jewitt, C. and Kress, G. (eds) (2003) Multimodal Literacy. London: Peter Lang.

- Jones, S. (ed) (1999) Doing Internet Research: Critical Issues and Methods for Examining the Net. Thousand Oaks, CA: Sage.

-Knobel, M. and Healy, A. (1998) 'Critical literacies: an introduction', in M. Knobel and A. Healy (eds), Critical Literacies in the Primary Classroom. Newtown, NSW: Primary English Teaching Association. pp. 1-12.

-Kress, G. (2003) Literacy in the New Media Age. London: Routledge.

-Kress, G. and Van Leeuwen, T. (1996) Reading Images: The Grammar of Visual Design. London: Routledge.

-Kress, G. and Van Leeuwen, T. (2001) Multimodal Discourse: The Modes and Media of Contemporary Communication. London: Edward Arnold.

- Lankshear, C., Bigum, C., Green, B., Honan, E., Durrant, C., Morgan, W., Murray, J., Snyder, I. and Wild, M. (1997) Digital Rhetorics: Literacies and Technologies in Education - Current Practices and Future Directions. Canberra: Department of Employment, Education, Training and Youth Affairs.

-Lankshear, C. and Knobel, M. (2003) New Literacies: Changing Knowledge and Classroom Learning. Buckingham and Philadelphia, PA: Open University Press.

- Lankshear, C. and Snyder, I. with Green, B. (2000) Teachers and Technoliteracy: Managing Literacy, Technology and Learning in Schools. Sydney: Allen and Unwin.

- Laurillard, D. (1993) Rethinking University Teaching: A Framework for the Effective Use of Educational Technology. London: Routledge.

-Lave, J. and Wenger, E. (1991) Situated Learning: Legitimate Peripheral Participation. Cambridge: Cambridge University Press.

- LeCourt, D. (1998) 'Critical pedagogy in the computer classroom: politicizing the writing space', Computers and Composition, 15 (3): 275-95.

- Lenhart, A. and Madden, M. (2005) 'Teen content, creators and consumers. PEW Internet and American Life Project: Family, friends and community'. 
Retrieved online 22 December 2005 at: http://www.pewinternet.org/PPF/r/166/report_display.asp.

-Livingstone, S. (2002) Young People and New Media: Childhood and the Changing Media Environment. London: Sage.

-Livingstone, S. and Bober, M. (2005) 'UK children go online: final report of key project findings', London: London School of Economics and Political Science. Retrieved 2 June 2005 online at: http://www. children-go-online.net.

-Manovich, L. (2001) The Language of New Media. Cambridge, MA: MIT Press. Merchant, G. (2001) 'Teenagers in cyberspace: language use and language change in Internet chatrooms', Journal of Research in Reading, 24: 293-306.

-O'Hear, S. and Sefton-Green, J. (2004) 'Style, genre and technology: the strange case of youth culture online', in I. Snyder and C. Beavis (eds), Doing Literacy Online: Teaching, Learning and Playing in an Electronic World. Creskill, NJ: Hampton Press. pp. 121-43.

-Pacey, A. (1983) The Culture of Technology (1st edn). Oxford: Blackwell.

-Pahl, K. and Rowsell, J. (2005) Literacy and Education: Understanding the New Literacy Studies in the Classroom. London: Paul Chapman.

-Prensky, M. (2005) Don't Bother Me, Mom - I'm Learning: How Computer and Video Games are Preparing your Kids for Twenty-first Century Success and How you can Help. New York: Paragon House.

-Rideout, V., Roberts, D. F. and Foehr, U. G. (2005) 'Generation M: Media in the lives of 8-18 year-olds'. Retrieved online 22 December 2005 at: http://www.kff.org/entmedia/entmedia030905pkg.cfm.

-Rogoff, B. (1984) 'Introduction: Thinking and learning in social context', in B. Rogoff and J. Lave (eds), Everyday Cognition: Cognitive Development in a Social Context. Cambridge, MA: Harvard University Press. pp. 1-8.

-Rogoff, B. (1990) Apprenticeship in Thinking: Cognitive Development in a Social Context. New York: Oxford University Press.

-Rogoff, B. (1995) 'Observing sociocultural activity on three planes: participatory appropriation, guided participation, apprenticeship', in J. Wertsch, P. del Rio and A. Alvarez (eds), Sociocultural Studies of Mind. New York: Cambridge University Press. pp. 139-64.

-Russell, D. (2002) 'Looking beyond the interface: activity theory and distributed learning', in M. Lea and K. Nicoll (eds), Distributed Learning. London: Routledge. pp. 64-82.

-Scribner, S. and Cole, M. (1981) The Psychology of Literacy. Cambridge, MA: Harvard University Press.

-Snyder, I. (ed.) (1997) Page to Screen: Taking Literacy into the Electronic Era. Melbourne: Allen and Unwin.

-Snyder, I. (1999) 'Packaging literacy, new technologies and "enhanced" learning', Australian Journal of Education, 43 (3): 287-301.

-Snyder, I. (2000) 'Literacy and technology studies: past, present, future', Australian Educational Researcher, 27 (1): 97-119. 
-Snyder, I. (2001) 'A new communication order: researching literacy practices in the network society', Language and Education, 15 (2-3): 117-31.

-Snyder, I. (ed.) (2002) Silicon Literacies: Communication, Innovation and Education in the Electronic Era. London: Routledge.

-Snyder, I. and Bulfin, S. (2005) 'Being digital in home, school and community'. Retrieved online 3 June 2005 at: http://community.education.monash.edu.au/projects/beingdigital/.

-Snyder, I., Angus, L. and Sutherland-Smith, W. (2002) 'Building equitable literate futures: home and school computer-mediated literacy practices and disadvantage', Cambridge Journal of Education, 32 (3): 367-83.

-Street, B. (1984) Literacy in Theory and Practice. Cambridge: Cambridge University Press.

-Street, B. (1995) Social Literacies: Critical Approaches to Literacy Development, Ethnography and Education. London: Longman.

-Street, B. (ed.) (2001) Literacy and Development: Ethnographic Perspectives. London: Routledge.

-Takayoshi, P., Huot, E. and Huot, M. (1999) 'No boys allowed: the World Wide Web as a clubhouse for girls', Computers and Composition, 16 (1): 89-106.

-Thomas,A. (2005) 'Children online: learning in a virtual community of practice', e-Learning, 2 (1): 27-38.

-Trumble,W. R. and Stevenson, A. (2002) (eds) New Shorter Oxford English Dictionary on Historical Principles (5th edn). New York: Oxford University Press.

-Turkle, S. (1995) Life on the Screen: Identity in the Age of the Internet. New York: Simon and Schuster.

-Vygotsky, L. (1962) Thought and Language, trans. E. Hanfmann and G. Vakar. Cambridge, MA: MIT Press.

-Walton, M. (2004) 'Behind the screen: the language of Web design', in I. Snyder and C. Beavis (eds), Doing Literacy Online: Teaching, Learning and Playing in an Electronic World. Cresskill, NJ: Hampton Press. pp. 91-119.

-Williams, R. (1975) Television: Technology and Cultural Form (1990, 2nd edn). London: Routledge.

-Williams, R. (1976) Keywords: A Vocabulary of Culture and Society. London: Fontana.

-Williams, R. (1983) [1958] Culture and Society, 1780-1950. New York: Columbia University Press.

-Yallop, C., Bernard, J. R. L., Blair, D., Butler, S., Delbridge, A., Peters, P. and Witton, N. (2005) (eds) Macquarie Dictionary, 4th edn. Sydney: Macquarie Library. 